Brit. F. vener. Dis. (1970) 46, 323

\title{
Preservation of Trichomonas vaginalis in liquid nitrogen
}

\author{
G. D. WASLEY \\ Department of Medical Microbiology, St. Thomas's Hospital Medical School, London, S.E.1. \\ C. F. A. RAYNER \\ Venereal Diseases Reference Laboratory (P.H.L.S.), Ashfield Street, London, E.1.
}

In recent years some attention has been focused on the low temperature storage of various protozoa.

The purpose of this work was to confirm that Trichomonas vaginalis can be preserved for several months at a temperature of $-196^{\circ} \mathrm{C}$. in liquid nitrogen.

Weinman and McAllister (1947), who successfully preserved a number of pathogenic protozoa, failed to preserve $T$. vaginalis, and only a proportion of their experiments with Trichomonas hominis were successful. No preservative was included in their cultures and the temperature was lowered only to $-15^{\circ} \mathrm{C}$. McEntegart (1954) preserved a number of species of Trichomonas at $-79^{\circ} \mathrm{C}$. in the presence of glycerol in a solid carbon dioxide/alcohol mixture; he obtained some viable $T$. vaginalis organisms after 4 months' storage, but there was evidence of slow deterioration. He suggested that a temperature of $-190^{\circ} \mathrm{C}$. would give better results. Lovelock and Bishop (1959) used dimethyl sulphoxide in place of glycerol as a preservative for the storage of human and bovine red cells and of spermatozoa. This agent was suggested as a preservative preferable to glycerol because of its greater capacity for permeating cells in aqueous electrolytes. A slow permeation of glycerol into $T$. vaginalis would explain the comparative lack of success with this protozoon up to that time. Walker and Ashwood-Smith (1961) considered that dimethyl sulphoxide was less toxic than glycerol in the storage of trypanosomes.

Diamond (1961) applied the use of dimethyl sulphoxide to the preservation of Entamoeba histolytica and successfully stored these organisms for 91 days in liquid nitrogen. Diamond, Bartgis, and Reardon (1965) applied a similar technique to the storage of $T$. vaginalis, 5 per cent. dimethyl sulphoxide being added as a preservative. Viable organisms were obtained after 2 years' storage in liquid nitrogen vapour at $-170^{\circ} \mathrm{C}$. The viability of the trichomonads was demonstrated by the fact that 29 of 30 mice died after intraperitoneal inoculation of a 48-hr-old subculture from the stored flagellates.

\section{Materials and methods}

$T$. vaginalis cultures, freshly isolated from clinical material, and stock culture strains were used.

\section{CULTURE MEDIUM}

(a) Cysteine-peptone-liver-maltose (CPLM) medium described by Johnson and Trussell (1943) and quoted by Trussell (1947) was prepared with chloromycetin ( $1 \mathrm{mg} . / 1 \mathrm{ml}$.), or penicillin (8300 units $/ \mathrm{ml}$.) and streptomycin $(0.83 \mathrm{mg} . / \mathrm{ml}$.) added.

(b) Oxoid Trichomonas medium No. 2 described by Bushby and Copp (1955) and Squires and MacFadzean (1962) and modified (Squires, personal communication, 1969).

(c) The medium described by Stenton (1957).

\section{CULTURE METHOD}

24-hr-old cultures of fifteen strains of $T$. vaginalis were inoculated into CPLM or Stenton's medium, incubated at $37^{\circ} \mathrm{C}$., and examined microscopically after $18 \mathrm{hrs}$. These cultures were centrifuged to concentrate the organisms and the deposits used in the preservation experiment.

\section{PRESERVATION METHOD}

$0.9 \mathrm{ml}$. quantities of Trichomonas cultures were gently mixed with $0.1 \mathrm{ml}$. dimethyl sulphoxide, transferred into $1 \mathrm{ml}$. glass ampoules, sealed, and labelled.

The sealed ampoules were chilled to $4^{\circ} \mathrm{C}$. and the temperature was then lowered $1^{\circ} \mathrm{C}$. every minute for $90 \mathrm{~min}$. in the liquid nitrogen vapour (temp. $-160^{\circ} \mathrm{C}$. to $-170^{\circ} \mathrm{C}$. approx.). The ampoules were then immersed in the liquid nitrogen (temp. $-196^{\circ} \mathrm{C}$.).

\section{RE-ACTIVATION FROM LIQUID NITROGEN}

On removal from the liquid nitrogen the ampoules were immediately immersed in a beaker of water $\left(37^{\circ} \mathrm{C}\right.$.) for $5 \mathrm{~min}$. to warm the contents sufficiently to enable the $T$. vaginalis to activate. Wet preparations were prepared and examined microscopically. The remainder of the material from the ampoules was 
inoculated into the two culture media and incubated at $37^{\circ} \mathrm{C}$.

\section{Results}

DEFINITION OF POSITIVE CULTURE OR PREPARATION

For the purpose of this paper a positive or viable culture or preparation is one in which the trichomonads are morphologically identifiable and motile.

\section{DEFINITION OF NEGATIVE CULTURE OR PREPARATION}

A negative culture or preparation is one in which there are no trichomonads or the examined object is morphologically unidentifiable and non-motile.

\section{PRESERVATION OF TRICHOMONADS}

The Table shows that all the cultures of fifteen strains of $T$. vaginalis stored at $-196^{\circ} \mathrm{C}$. were capable of producing growth of the organism in the CPLM medium. Of the thirteen cultures stored for 6 months, all grew after sub-culture into the CPLM medium and twelve of the thirteen were positive on direct microscopical examination of the ampoule contents.

As no counts were made either before or after storage, the percentage of viable flagellates in any one culture was not obtained. Observations from the direct microscopical examination of the stored cultures that had been removed from liquid nitrogen and warmed to $37^{\circ} \mathrm{C}$. showed that all the flagellates, motile or not, were identifiable as trichomonads. This recognition of non-motile forms is unlike the situation usually presenting itself in the examination of material for trichomonads where only motile forms are acceptable.

The sub-cultures which were positive all contained motile forms. The Table also shows that all subcultures in the CPLM medium were successful, whereas sub-cultures in the Oxoid No. 2 medium were successful only with flagellates which had been stored for no longer than 2 weeks. This is probably a reflection of the efficiency of the CPLM medium rather than of the inefficiency of the freezing technique. The CPLM medium has been shown to be an extremely sensitive means for the detection of the flagellate (Rayner, 1968a). Experiments have shown that the Oxoid No. 2 medium requires an inoculum of about 7,000 organisms to initiate growth (Rayner, 1968b, unpublished data), whereas the CPLM medium requires only between one and forty flagellates. This suggests that the number of viable trichomonads was reduced after about 2 weeks' storage, although a sufficient number remained viable up to 6 months for them to be observed microscopically directly after thawing.

\section{Discussion}

As Diamond and others (1965) have shown, viable $T$. vaginalis can still be obtained after 2 years' storage in liquid nitrogen vapour. They used only one strain of the organism, however, whereas in the present work five strains of $T$. vaginalis were examined after 6 months' storage and found still viable. There is no reason to suppose that they would not have survived for a longer period had the testing time been prolonged.

This method of preservation should prove of great time-saving value to those working with these protozoa. Stock strains of $T$. vaginalis which would otherwise have to be subcultured 2 or 3 times a week could be stored for long periods for reference purposes.

Little is known about possible changes in the antigenic properties of the trichomonads after a long period of storage. The experiments of Lindgren and

TABLE Preservation of Trichomonas vaginalis in liquid nitrogen

\begin{tabular}{|c|c|c|c|c|c|c|}
\hline \multirow{2}{*}{$\begin{array}{l}\text { Preservation } \\
\text { time }\end{array}$} & \multirow{2}{*}{$\begin{array}{l}\text { Culture medium used } \\
\text { in liquid nitrogen }\end{array}$} & \multirow{2}{*}{$\begin{array}{l}\text { Number of ampoules } \\
\text { and strain }\end{array}$} & \multirow{2}{*}{$\begin{array}{l}\text { Dirrct examination of } \\
\text { ampoule culture }\end{array}$} & \multicolumn{3}{|c|}{ Examination of sub-culture } \\
\hline & & & & $C P L M$ & Oxoid No. & 2 medium \\
\hline $\begin{array}{l}24 \mathrm{hrs} \\
48 \mathrm{hrs} \\
1 \mathrm{wk} \\
2 \mathrm{wks} \\
4 \mathrm{wks} \\
12 \mathrm{wks}\end{array}$ & $\begin{array}{l}\text { CPLM } \\
\text { CPLM } \\
\text { CPLM } \\
\text { CPLM } \\
\text { CPLM } \\
\text { CPLM } \\
\text { CPLM } \\
\text { CPLM } \\
\text { CPLM } \\
\text { Stenton } \\
\text { CPLM } \\
\text { CPLM } \\
\text { Stenton }\end{array}$ & $\begin{array}{l}\times 1 \text { Clinical } \\
\times 1 \text { Clinical } \\
\times 2 \text { Clinical } \\
\times 2 \text { Clinical } \\
\times 1 \text { Stock strain (A) } \\
\times 2 \text { Clinical } \\
\times 1 \text { Stock strain (A) } \\
\times 2 \text { Clinical } \\
\times 1 \text { Stock strain (A) } \\
\times 1 \text { Stock strain (B) } \\
\times 2 \text { Clinical } \\
\times 2 \text { Stock strain(A)(B) } \\
\times 9 \text { Stock strain(A)(B) } \\
\text { (C) }\end{array}$ & $\begin{array}{l}1 / 1+\text { ve } \\
1 / 1+v e \\
2 / 2+v e \\
2 / 2+\text { ve } \\
1 / 1 \text {-ve } \\
2 / 2+\text { ve } \\
1 / 1+\text { ve } \\
2 / 2+\text { ve } \\
1 / 1 \text {-ve } \\
1 / 1 \text {-ve } \\
2 / 2+\text { ve } \\
2 / 2+\text { ve } \\
8 / 9+\text { ve }\end{array}$ & $\begin{array}{l}1 / 1+v e \\
1 / 1+v e \\
2 / 2+v e \\
2 / 2+v e \\
1 / 1+v e \\
2 / 2+v e \\
1 / 1+v e \\
2 / 2+v e \\
1 / 1+v e \\
1 / 1+v e \\
2 / 2+v e \\
2 / 2+v e \\
9 / 9+v e\end{array}$ & $\begin{array}{l}1 / 1+\mathrm{ve} \\
1 / 1+\mathrm{ve} \\
1 / 2+\mathrm{ve} \\
1 / 2+\mathrm{ve} \\
\star \\
2 / 2-\mathrm{ve} \\
\star \\
2 / 2-\mathrm{ve} \\
\star \\
\star \\
2 / 2-\mathrm{ve} \\
2 / 2-\mathrm{ve} \\
\star\end{array}$ & $\begin{array}{l}(1 / 2-v e) \\
(1 / 2-v e)\end{array}$ \\
\hline
\end{tabular}


Ivey (1964) and Diamond and others (1965) with mice suggest that there is little or no loss of virulence.

Nielsen (1965) has shown that strains of $T$. vaginalis have been isolated which are increasingly insensitive to metronidazole which is the specific drug for treatment of $T$. vaginalis infestations of the human genital tract. There is virtually no evidence that resistance is developing in Great Britain at present (McFadzean, Pugh, Squires, and Whelan, 1969). Should such a situation eventually arise, however, the storage of these strains would prove valuable for research and reference purposes.

\section{Summary}

Strains of Trichomonas vaginalis were successfully preserved in liquid nitrogen in the presence of dimethyl sulphoxide. It is suggested that this method would be useful as a means of storing strains of Trichomonas vaginalis.

\section{References}

Bushiy, S. R. M., and Copp, F. C. (1955) f. Pharm. Pharmacol., 7, 112.

Diamond, L. S. (1961) f. Parasit., 47, no. 4, sect. 2, p. 28.

- - Bartgis, I. L., and Reardon, L. V. (1965) Cryobiology, 1, 295.

Johnson, G., and Trussell, R. E. (1943) Proc. Soc. exp. Biol. (N.Y.), 54, 245.
Lindgren, R. D., and Ivey, M. H. (1964) F. Parasit., 50 226.

Lovelock, J. E., and Bishop, M. W. H. (1959) Nature (Lond.), 183, 1394.

McEnTEgART, M. G. (1954) f. Hyg. (Lond.), 52, 545.

McFadzean, J. A., Pugh, I. M., Squires, S. L., and Whelan, J. P. F. (1969) Brit. F. vener. Dis., 45, 161.

Nielsen, R. (1965) Proc. Fennu-Scand. Ass. Derm, p. 118.

RAYNER, C. F. A. (1968a) Brit. F. vener. Dis., 44, 63.

- (1968b). Unpublished data.

SQuires, S. L. (1969) Personal communication. and McFadzean, J. A. (1962) Brit. F. zener. Dis., 38, 218.

Stenton, P. (1957) F. med. Lab. Tech., 14, 228.

TRUSSELL, R. E. (1947) 'Trichomonas vaginalis and Trichomoniasis', p. 42. Thomas, Springfield, Ill.

WALKeR, P. J., and AshWOOD-Smith, M. J. (1961) Ann. trop. Med. Parasit., 55, 93.

Weinman, D., and McAllister, J. (1947) Amer. $\mathcal{F}$. Hyg., 45, 102.

Une méthode de préservation du Trichomonas vaginalis dans l'azote liquide

SOMMAIRE

Des souches de Trichomonas vaginalis furent conservées avec succès dans l'azote liquide en présence de diméthylsulfoxide. Ceci laisse penser que cette méthode peut être utile comme moyen de stocker des souches de Trichomonas vaginalis. 